\title{
Penguatan Pendidikan Karakter di Sekolah Dasar di Era Revolusi Industri 4.0
}

\author{
Zidniyati, \\ Fakultas Tarbiyah, IAI Ibrahimy Genteng Banyuwangi \\ e-mail: zidniyati@iaiibrahimy.ac.id
}

\begin{abstract}
The purpose of this study is to re-examine what is meant by character education, how to apply character education in several elementary schools, including methods and results, and to try to reformulate the appropriate character education model in the era of industrial revolution 4.0. The methodology of the study carried out in this paper is an analysis of studies from various sources of theory about character education and industrial revolution 4.0, and an analysis of studies of several character education practices carried out in several elementary schools / madrasah ibtidaiyyah (MI) in Banyuwangi region as well in the Jogjakarta Region. The results of the research from both the theoretical and of the practical analysis in this paper is that the application of character educationstill does not produce the results as expected. However, so far, there have been many elementary school level that have implemented character education according to the abilities of educator resources. Educator resources are the main determinant in achieving or not the goal of character education for each school that applies it, especially in terms of determining programs as a form of character education. It was also found that the results of character education applied to each school also varied, depending on how the educator's resources interpreted the objectives of the character education program in their respective schools.
\end{abstract}

Keywords: character education, elementary school, industrial revolution 4.0

\begin{tabular}{|c|c|c|}
\hline Accepted: & Reviewed: & Publised: \\
Desember 28 2018 & Januari 192019 & Februari 28 2019 \\
\hline
\end{tabular}

\section{PENDAHULUAN}

Seiring dengan berjalannya waktu, saat ini peradaban manusia telah memasuki era revolusi industri 4.0. Sebuah era dimana informasi dan komunikasi antara manusia yang hidup di belahan bumi utara hingga selatan menjadi sangat

This work is licensed under Creative Commons Attribution Non Commercial 4.0 International License Available iaiibrahimy.ac.id 
cepat dan terasa dekat. Melalui akses jaringan berbasis internet, semua informasi yang dibutuhkan manusia dapat diperoleh hanya dengan memanfaatkan perangkat yang dilengkapi fasilitas Android tingkat tinggidengan cara menelusuri dunia maya menggunakan sebuah mesin pencarian. Tidak perlu waktu lama, cukup dalam hitungan detik, berbagai informasi maupun transaksi sampai pengambilan keputusan dapat dilakukan.

Melalui bentuk komunikasi secepat itu, semua transaksi bisnis dapat dilakukan secara cepat dan jauh lebih efisien dibanding dengan cara konvensional. Semua diskusi forum dapat dilakukan dari jarak jauh, semua keputusan dapat diambil walaupun anggota diskusi berada di tempat yang berbeda. Detail dari sebuah produk dapat dikemas dalam sebuah gambar visual dengan fasilitas audio yang jelas, sehingga seorang produsen dapat mengiklankan produknya dan calon konsumen dapat melihatnya dengan penelusuran sebuah mesin pencari informasi. Manusia dewasa, remaja, pun anak-anak saat ini dapat terhubung dan mengakses berbagai informasi dari segala penjuru dunia. Bagaimana kemudian bentuk-bentuk pendidikan dapat mengambil perannya secara tepat di era revolusi industri ini?

STEM, yang merupakan singkatan dari Science, Technology, Engineering, dan Mathematic diusung sebagai 4 bidang yang menjadi fokus kajian untuk menghadapi cepatnya laju peradaban di era revolusi industri ini. Bagaimanakah dengan bidang kajian ilmu lainnya? Dikesampingkan kah? Tentunya tidak, karena Science memuat berbagai pengetahuan yang terbagi dalam dua kajian ilmu, yakni Social Science dan Natural Science. Dalam Natural Science dikaji berbagai ilmu alam untuk membekali peserta didik dan para akademisi dalam menggali keberlangsungan kehidupan di alam semesta ini, sementara dalam Social Science terdapat berbagai kajian ilmu yang dapat digunakan untuk menjadikan peradaban manusia menjadi lebih arif di saat menggunakan Natural Science untuk keberlangsungan hidup. Pertanyaan selanjutnya adalah, bagaimanakah peran pendidikan karakter yang digaungkan oleh pemerintah melalui pendidikan nasional, terutama dengan kemasan kurikulum 2013? Dalam kajian berikut ini akan dikupas mengenai selintas tahapan revolusi industri 4.0, konsep pendidikan karakter serta beberapa contoh penerapannya di beberapa kelas pembelajaran di Sekolah Dasar/Madrasah Ibtidaiyyah. Pada bagian akhir akan dilakukan penyimpulan mengenai format pendidikan karakter seperti apa yang harus dikuatkan untuk menyiapkan generasi agar mampu bersikap arif di era revolusi industri 4.0 atau di era berikutnya. 


\section{METODE PENELITIAN}

Penelitian ini menggunakan studi kepustakaan. Penelitian ini dikaji menggunakan kajian analisis berbagai literatur. Di samping itu, beberapa kajian analisis juga mengambil dari beberapa contoh praktik di kelas. Kirk dan Miller, sebagaimana Moeloeng (2006) menyatakan bahwa penelitian kualitatif ialah tradisi tertentu dalam ilmu pengetahuan sosial yang secara fundamental bergantung pada pengamatan pada manusia dalam kawasannya sendiri dan berhubungan dengan orang-orang tersebut dalam bahasanya dan dalam peristilahannya. Sedangkan pendekatan kepustakaan adalah kajian yang menggunakan analisis data berdasarkan bahan tertulis, bahan kepustakaan berupa catatan yang terpublikasikan, buku, majalah, surat kabar, naskah, jurnal ataupun artikel.

\section{HASIL ANALISIS DAN PEMBAHASAN}

\section{A. Apakah yang Dimaksud Revolusi industri 4.0?}

Istilah Industrial Revolution 4.0 (ir 4.0) pertama kali dikenalkan oleh Profesor Klaus Schwab (2016), seorang ahli ekonomi melalui bukunya yang berjudul "The Fourth Industrial Revolution". Pada buku tersebut terungkap gagasan dari Schwab mengenai revolusi industri 4.0. Ir 4.0 ini dinyatakan telah mengubah hidup, pola pikir hingga cara kerja manusia. Dalam perkembangannya, revolusi industri 4.0 ini memberikan (1) tantangan sekaligus dampak bagi generasi muda bangsa Indonesia dan juga (2) pada dunia pendidikan di Indonesia. Perkembangan muncul dengan ditandai mulainya digitalisasi sistem pendidikan yang mengarahkan setiap unsur dalam bidang pendidikan untuk mampu melakukan penyesuaian dengan laju perubahan yang terjadi. Satu diantara beberapa contohnya adalah sistem pembelajaran di dalam kelas yang telah memanfaatkan falisitas akses internet. Misalnya dengan membawa murid menjelajahi dunia maya untuk menggali satu atau beberpa informasi terkait materi pembelajaran di kelas.

Kapankah revolusi industri berawal dan mengapa saat ini tiba-tiba telinga kita akrab dengan istilah revolusi industri 4.0. Adakah revolusi-revolusi industri sebelumnya? Schwab (2016:11) dalam bukunya menguraikan ada empat era yang menandai tahapan revolusi industri dengan menyatakan:

The first industrial revolution spanned from about 1760 to around 1840.Triggered by the construction of railroads and the invention of the steam engine, it ushered in mechanical production. The second industrial revolution, which started in the late 19th century and into the early $20^{\text {th }}$ century, made mass production possible, fostered by the advent of electricity and the assembly line. The third industrial revolution began in the 1960s. It is usually called the computer or digital revolution because it was catalysed by the development of 
semiconductors, mainframe computing (1960s), personal computing (1970s and 80s) and the internet (1990s).

Mindful of the various definitions and academic arguments used to describe the first three industrial revolutions, I believe that today we are at the beginning of a fourth industrial revolution. It began at the turn of this century and builds on the digital revolution. It is characterized by a much more ubiquitous and mobile internet, by smaller and more powerful sensors that have become cheaper, and by artificial intelligence and machine learning.

Berdasarkan pernyataan tersebut dapatlah diuraikan pembagian era revolusi industri sebagai berikut.

1) Revolusi industri yang pertama terjadi sekitar abad 18, yakni tahun 1760 hingga 1840 yang ditandai dengan konstruksi rel kereta api dan penemuan mesin uap (Schwab, 2016:10). Era ini dikenal juga dengan istilah revolusi industri 1.0. Penemuan pada era ini mengantarkan pada produksi mekanis. Munculnya mesin uap pertama menimbulkanberkembangnyakemajuan perekonomian dunia. Penemuan pada masa ini menjadikan terjadinya pergeseran tenaga ke mesin-mesin produksi mekanik.

2) Revolusi industri kedua terjadi pada akhir abad 19 hingga awal abad 20, atau sekitar tahun 1870 atau dikenal dengan istilah revolusi industri 2.0. Pada era ini munculproduksi massal berbagai produk didorong oleh munculnya listrik dan jalur perakitan (assembly line) antara lain mesin pembangkit listrik, telepon, mobil, dan pesawatterbang.

3) Revolusi industri ketiga terjadi pada 1960an atau sekitar tahun 1969 atau dikenal dengan istilah revolusi indiustri 3.0. Masa ini seringkali disebut masa revolusi komputer atau digital karena terjadi percepatan perubahan dengan adanya pengembangan semikonduktor dengan komputasi mainframe. Pada tahun ini muncul perangkat komputer walaupun dalam kemampuan yang sederhana dibanding saat ini. Muncul pula akses internet digital yang selanjutnya memberikan pengaruh pada budaya dan peradapan zaman.

4) Revolusi industri keempat atau yang dikenal revolusi industri 4.0 terjadi pada abad ke-20 ini. Generasi yang hidup di zaman ini dikenal dengan istilah generasi $\mathrm{Z}$ atau generasi millenial. Di abad ke-20 ini terjadi perkembanganteknologidaninformasiyang semakin pesat dibanding dengan masa sebelumnya. Berbagai perangkat informasi telah menggunakan teknologi yang bersifat digital. Produk yang muncul antara lain smartphone dengan sistem android yang cukup canggih, internet seluler berada dimana-mana dengan sensor yang lebih kecil, dengan perangkat yang lebih kecil dan lebih kuat 
sehingga menjadi lebih murah, dan dengan disertai sistem kecerdasan buatan dan sistem pembelajaran mesin. Kecanggihan initercermin dengan mampu digunakannya sebagai alat komunikasi jarak jauh dan mampu menampilkan visualsituasi terkini pengguna komunikasi. Di samping itu, semua orang dapat mengakses informasi, baik menyebarkan maupun mengambil informasi dengan mudah dan cepat, dan efisien baik dari segi waktu maupun biaya.

\section{B. Apakah Peran Pendidikan di Era Revolusi Industri 4.0?}

Peran pendidikan dalam mempersiapkan generasi di era revolusi industri 4.0 saat ini adalah menyiapkan lulusan yang mampu berinteraksi dengan manusia dari berbagai belahan bumi dan tentunya dibekali kemampuan interpersonal dan intrapersonal secara sosial dan emosional yang kuat. Kriteria lulusan yang dicanangkan oleh pemerintah Indonesia saat ini sesuai dengankurikulum 2013 sebagaimana Maemunah (2018: 5) merangkum kriteria lulusan. Lulusan dituntut untuk dapat memiliki kemampuan dalam.

(1) Memecahkan masalah. Kemampuan ini sangat bermanfaat bagi lulusan agar dapat digunakan dalam menghadapi berbagai situasi beserta resiko yang mengiringinya yang tentunya akan semakin banyak bervariasi tingkat kerumitannya di situasi yang serba cepat dan tidak menentu di abad 21 ini.

(2) Berfikir kritis. Kemampuan ini juga sangat dibutuhkan saat lulusan dihadapkan pada persoalan yang melibatkan banyak hal dan pengambilan keputusannya juga tentunya akan memberi pengaruh pada diri sendiri dan orang lain.

(3) Inovatif. Pemecahan masalah dan kemampuan berfikir kritis yang diharapkan dimiliki oleh lulusan harus yang mengandung kebaruan, karena segala hal di era ini juga memiliki kebaruan dari berbagai sisi. Bilamana lulusan tidak terlatih untuk menemukan satu kebaruan dalam proses pemecahan masalah dan dalam proses berfikirnya, tentunya keputusan yang diambil akan mengarah pada solusi yang mungkin justru menimbulkan persoalan lain.

(4) Enterpreuner. Pada era 21 ini akan sangat dimungkinkan terjadinya penurunan atau bahkan hilangnya beberapa profesi yang di era sebelumnya ada dan tergantikan dengan profesi-profesi baru. Misalkan, saat ini muncul profesi yang diacukan pada para youtuber. Sebuah profesi yang dalam usahanya memanfaatkan salah satu aplikasi dunia maya youtube untuk memasarkan produk. Konten yang ditampilkan dapat sangat bervariasi. Siapa saja dapat menyaksikan hasil para youtuber ini hanya dengan hitungan detik dan dengan kemudahan. Kemampuan yang dibutuhkan adalah jiwa enterpreneur. Jiwa yang dapat terampil memikirkan bagaimana sebuah produk dapat diminati pasar sehingga dapat menghasilkan uang.

Karena di era revolusi industri 4.0 terjadi hubungan yang mudah dengan semua manusia dari berbagai belahan bumi, serta memudahkan manusia untuk saling bertemu dengan berbagai kebutuhannya, maka terjadilah situasi dimana keberadaan beberapa orang dari berbagai kultur di satu tempat yang sama dalam 
beberapa waktu lamanya. Maka, di situasi semacam itu, terjadi pertemuan nilainilai yang dibawa oleh setiap orang dari berbagai kultur. Dengan tujuan agar interaksi orang-orang dari berbagai kultur dengan berbagai nilai yang dibawanya inilah, beberapa pendapat mengatakan bahwa aspek etika dalam berinteraksi menjadi sangat dibutuhkan. Rahman dan Ningsih (2018: 5) menyatakan bahwa perlu dilakukan penguatan identitas diri melalui pendidikan multikultural yang salah satu aspek yang perlu diajarkan adalah etika. Etika merupakan aspek terpenting dalam terwujudnya generasi muda yang paham mengenai konsep pendidikan multikultural, keberhasilan dalam penguatan etika dipengaruhi oleh lembaga pendidikan, pendidik dengan tugas dan tanggung jawabnya,dan murid dengan tugas dan tanggung jawabnya. Diharapkan dengan konsep awal pembenahan etika dikalangan generasi muda nilai-nilai dari pendidikan multikultural mampu diimplementasikan dengan benar untuk meminimalisir berbagai permasalahan-permasalah pendidikan di Indonesia dan sesuai dengan tujuan pendidikan multikultural yang menekankan sebuah filosofi pluralism budaya ke dalam system pendidikan yang didasarkan pada prinsip-prinsip persamaan (equality), saling menghormati dan menerima serta memahami dana dan komitmen moral untuk sebuah keadilan social yang nantinya dapat dijadikan nilai utama agar mampu menjawab berbagai konflik horizontal dan vertical dalam dunia pendidikan di era revolusi industri 4.0.

Berdasarkan uraian mengenai kriteria lulusan sesuai kurikulum 2013 serta gagasan pendidikan multibudaya, maka ada 4 kemampuan dan satu aspek penting yang dibutuhkan untuk disampaikan pada peserta didik. Empat kemampuan tersebut adalah kemampuan memecahkan masalah, kemampuan berfikir kreatif, kemampuan berinovasi, dan kemampuan enterpreneurship. Etika menjadi aspek penting untuk diajarkan dalam sebuah pendidikan, maka dapat dikatakan bahwa nilai-nilai yang memang dapat diajarkan pada setiap generasi adalah nilai-nilai pembangun karakter yang mengarahkan setiap generasi untuk hidup berdampingan secara damai bersama orang-orang dari berbagai kultur.

Allah SWT mengutus Nabi Muhammad SAW ke bumi adalah untuk satu tujuan yang mulia, yakni menyempurnakan akhlak manusia di muka bumi ini. Maka dari itu segala program pendidikan karakter di setiap madrasah setingkat sekolah dasar juga bertujuan untuk menyempurnakan akhlak setiap warga sekolah, termasuk guru, murid, karyawan, maupun walimurid. Isi pendidikan akhlak yang diberikan dalam suatu sekolah atau madrasah adalah nilai-nilai moralitas yang biasanya diacukan pada aturan agama, demikian pula isi dari pendidikan karakter atau pendidikan nilai adalah nilai-nilai moral yang universal yang disepakati untuk dijadikan pedoman dan dibiasakan untuk dicerminkan dalam perilaku sehari-hari.

Sejak dahulu hingga saat era revolusi industri 4.0 saat ini, semua segi kehidupan manusia tidak terbebas dari nilai. Oleh karenanya, dalam pendidikan 
pun harus juga sepatutnya mengajarkan nilai. Dua di antara sepuluh alasan yang diajukan Lickona, sebagaimana dikutip oleh Zidniyati (2017) tentang mengapa sekolah harus membuat komitmen yang jernih dan sepenuh hati untuk mengajarkan nilai-nilai moral dan mengembangkan karakter yang baik adalah bahwa peran sekolah sebagai pendidik moral menjadi lebih penting pada saat jutaan anak mendapatkan sedikit pembelajaran moral dari orang tua atau akses yang kurang dari pusat pendidikan keagamaan di masa-masa pertengahan kanakkanak. Sebuah masa di mana, seharusnya, anak-anak memperoleh teladan moral atau nilai pembangun karakter dari lingkungan terdekatnya. Satu alasan kuat lainnya yang diajukan Lickona (1991: 20) adalah karena "there is no such thing as value-free education". Maknanya adalah, semua satuan pendidikan harus mengajarkan nilai. Nilai-nilai yang tentunya dibutuhkan untuk perkembangan belajar anak. Termasuk di antara nilai-nilai tersebut adalah melalui budaya sikap yang (1) ditunjukkan guru dan semua orang dewasa di lingkungan sekolah saat bersikap pada siswa, (2) budaya sikap yang ditunjukkan sekolah kepada orang tua, serta (3) budaya sikap siswa terhadap semua staf di sekolah dan orang lain. Dalam hal ini, Lickona menegaskan untuk tidak lagi bertanya, "Should schools teach values?" (haruskah sekolah mengajarkan nilai-nilai (pembangun karakter)?), namun lebih baik menanyakan "Which values will they teach?" (nilai-nilai yang mana yang akan diajarkan?) dan "How well will they teach them?" (Seberapa bagus mereka akan mengajarkan nilai-nilai tersebut?).

Lickona merumuskan proses pengembangan karakter dapat dilakukan dengan cara menanamkan nilai-nilai pembangun karakter terpuji melalui tiga tahap, yakni moral knowing (pengetahuan tentang moral), moral feeling (perasaan tentang moral), dan moral action (perbuatan bermoral). Proses pengembangan karakter ini diawali dengan pemberian pemahaman pada siswa tentang suatu nilai moral, dilanjutkan dengan pelibatan diri siswa secara emosional pada nilai yang diajarkan sehingga siswa meyakini bahwa nilai moral tersebut perlu dijadikan panduan dalam hidupnya, dan dimaknai dengan pembiasaan berperilaku sesuai nilai yang diyakini tersebut. Memang tidak singkat waktu yang dibutuhkan untuk mengembangkan karakter positif pada diri siswa. Namun seiring dengan tugas perkembangannya, karakter setiap siswa dapat dikembangkan secara terusmenerus.

Ki Hadjar Dewantara (2013:20), tokoh pendidikan di Indonesia yang hidup di tahun 1889- 1959 mendefinisikan pendidikan sebagai tuntunan di dalam hidup tumbuhnya anak-anak. Bilamana pendidikan merupakan tuntunan maka sudah semestinya isi dari pendidikan itu sendiri adalah nilai-nilai yang dijadikan pedoman hidup. Menurut Ki Hadjar Dewantara, pendidikan dimaksudkan untuk 
menuntun semua kekuatan kodrati yang dimiliki anak-anak, dengan tujuan agar anak-anak sebagai manusia dan juga selaku anggota masyarakat mampu meraih keselamatan dan kebahagiaan setinggi-tingginya.

Menurut Ki Hadjar Dewantara (2013:22-23) dasar jiwa anak dapat dipengaruhi oleh pendidikan. Dasar jiwa menurut Ki Hadjar Dewantara merupakan keadaan jiwa yang asli menurut kodratnya sendiri. Kodrat anak adalah sebagai manusia, dengan pengaruh dari sebuah pendidikan, seorang anak akan tetap bertumbuhkembang menjadi manusia, manusia yang baik atau manusia yang tidak baik karakternya. Pengaruh pendidikan sangatlah kuat pada watak anak. Ki Hadjar Dewantara membagi 3 aliran yang berkaitan dengan dasar jiwa anak dan kuatnya daya pendidikan.

Yang pertama adalah aliran dengan teori tabula rasa, sebuah aliran lama yang sekarang sudah hampir tidak diakui kebenarannya di kalangan kaum cendekiawan. Menurut aliran ini, anak yang terlahir di dunia itu diumpamakan sehelai kertas yang belum ditulisi, sehingga kaum pendidik boleh mengisi kertas kosong itu menurut kehendaknya. Dalam hal ini, pendidik berkuasa seluasnya untuk membentuk watak atau budi seperti yang diinginkan.

Aliran yang kedua adalah aliran negatif, yang berpendapat bahwa anak itu terlahir sebagai sehelai kertas yang telah ditulisi sepenuhnya, hingga tidak ada kemungkinan pendidikan dari siapapun dapat mengubah watak-wataknya anak. Pendidikan hanya dapat mengawasi dan mengamat-amati, jangan sampai ada pengaruh jahat yang mendekati anak. Jadi, pendidikan menurut aliran negatif ini dapat menolak pengaruh-pengaruh dari luar, akan tetapi mewujudkan budipekerti yang tidak nampak pada jiwa anak adalah suatu kemustahilan.

Aliran ketiga adalah aliran yang terkenal dengan nama 'convergentietheorie'. Teori ini mengajarkan bahwa anak terlahir seumpama sehelai kertas yang telah ditulisi penuh, akan tetapi semua tulisan itu suram/belum jelas. Menurut aliran ini, pendidikan berkewajiban dan berkuasa menebalkan/ memperjelas segala tulisan yang suram tersebut dan yang berisi baik. Segala tulisan yang mengandung arti jahat hendaknya dibiarkan, agar jangan sampai menjadi tebal, bahkan perlu dijadikan makin suram.

Berdasarkan gagasan Ki Hadjar Dewantara tersebut, dapatlah disimpulkan bahwa peran pendidikan memang menuntun anak untuk menjadi pribadi dengan karakter yang baik, karena setiap anak telah terlahir dengan membawa benih kebaikan. Bilamana para pendidik telah menuntaskan tugasnya dengan baik, maka benih keburukan yang juga terlahir bersama anak, akan dapat dinisbikan sampai tidak dapat bertumbuh dan berkembang. Gagasan ini tentunya meyakinkan para 
pendidik moral bahwa pendidikan nilai untuk mengembangkan karakter yang baik pada siswa adalah hal yang mungkin dilakukan.

Pestalozzi, pemikir pendidikan, filsuf Amerika, sekaligus kritikus sosial yang hidup di tahun 1859-1952, menyatakan bahwa manusia terlahir dengan membawa benih kebaikan sebagaimana yang dikutip oleh Heafford (1967: 61), "Man is good and seeks the good; his conscience only allows him to feel secure when he does the good; and if he is evil, it is surely because the way has been blocked, along which he wanted to be good."

Berdasarkan penyataan tersebut, Heafford memaknai bahwa setiap manusia terlahir dengan benih-benih intelektualitas di dalam dirinya, maka dengan demikian, setiap manusia terlahir dengan benih kebaikan manusia. Untuk itulah tujuan dari semua pendidikan adalah untuk merawat benih ini sehingga bertumbuh dan berkembang.

Dengan demikian dapat ditegaskan kembali bahwa setiap bayi terlahir dengan membawa benih kebaikan dan benih inilah yang selanjutnya selama perjalanan hidupnya harus dirawat dengan baik. Perawatan ini akan dapat dilakukan melalui berbagai cara, diantaranya dan paling penting adalah melalui pendidikan, baik formal maupun nonformal.

Senada dengan hal ini, Tillman (2016:1) salah satu penggagas living values education menyatakan bahwa ada empat kebutuhan dasar manusia yang akan mengarahkan perjalanan hidupnya yakni: (1) kebutuhan untuk dicintai (to be loved), (2) kebutuhan untuk dilindungi (to be saved), (3) kebutuhan untuk dihargai (to be respected), dan (4) kebutuhan untuk dipedulikan (to be cared). Berdasarkan keempat kebutuhan dasar inilah, para penggagas pendidikan nilai melalui program living values education melakukan serangkaian program yang pada prinsipnya menganggap bahwa setiap manusia terlahir dengan membawa benih kebajikan, dan karena itulah, dalam program ini menekankan berbagai cara agar benih kebaikan dapat terawat dengan subur. Tillman menegaskan bahwa lingkungan yang mampu megarahkan setiap anak untuk dapat hidup dan bertumbuh dengan atmosfer yang baik, maka benih kebaikan akan semakin menuju ke arah positif. Sebenarnya setiap penggagas pendidikan selalu memiliki fokus kajian tersendiri tentang pentingnya pendidikan karakter. Berbagai istilah yang digunakan pun beragam. Beberapa istilah yang digunakan antara lain adalah pendidikan karakter, pendidikan moral, pendidikan akhlak, pendidikan budi pekerti, living values education, dan values inculcation. Dalam tulisan ini istilah pendidikan karakter, pendidikan moral, pendidikan nilai, pendidikan budi pekerti dianggap serupa walaupun ada beberapa pendapat yang mengatakan tetap ada perbedaannya. Adapun living values education dipandang sebagai upaya untuk melakukan 
pendidikan karakter yang mendasarkan prinsip bahwa setiap manusia telah memiliki benih kebaikan, dan program living values berupaya untuk menghidupkan (kembali) kebaikan tersebut.

\section{Bagaimana Bentuk Pendidikan Karakter dalam Mengambil Peran di Era Revolusi Industri 4.0 Ini?}

Mudah dan cepatnya interaksi antar manusia di dunia ini dari belahan bumi utara hingga selatan, maka pendidikan karakter harus semakin diperkuat, diperjelas, diterapkan tanpa henti. Benturan berbagai nilai-nilai yang dibawa setiap orang dari budaya yang berbeda, menjadikan setiap individu harus memiliki prinsip hidup sesuai pedoman nilai yang membuat interaksi berjalan baik. Bila interaksi tidak berjalan baik, maka berbagai resiko yang merusak interaksi akan berujung pada rusaknya hubungan antar manusia yang mengarah pada tidak tercapainya kedamaian. Para penggagas pendidikan nilai, karena pendidikan karakter sendiri berisi pendidikan nilai-nilai pembangun karakter, terutama penggiat program LVE (living values education) berpendapat bahwa selama beberapa abad lamanya pendidikan karakter dilakukan, masih tetap belum membuahkan hasil yang maksimal. Hal ini terjadi oleh karena beberapa sebab, di antaranya program dari pendidikan nilai belum diterapkan secara holistik. Diane Tillman (2016:10), salah satu penggagas program LVE bersama timnya merumuskan program LVE yang bertujuan untuk memberikan panduan prinsip dan alat untuk pengembangan manusia secara holistik agar setiap individu memiliki (1) ketrampilan yang terasah dalam hal intrapersonal dan interpersonal baik sosial maupun emosional, serta memiliki (2) perspektif dan perilaku berbasis nilai.

Prinsip-prinsip pendidikan nilai dalam program living values education sendiri dibagi tiga unsur utama, sebagaimana dinyatakan oleh Drake (2016:12) yakni: (1) prinsip pada lingkungan belajar-mengajar, (2) prinsip tentang mengajarkan nilai-nilai, dan (3) prinsip terkait alam dari setiap individu dalam konteks dunia dan lingkup pendidikan.

1. Pinsip pada lingkungan belajar-mengajar:

a. pada saat nilai-nilai positif dan pencarian makna serta tujuan ditempatkan sebagai jantung dari kegiatan belajar-mengajar, maka pendidikan itu sendiri akan bermakna.

b. Belajar akan mengalami progres ketika dilakukan dalam komunitas belajar berbasis nilai, dimana nilai-nilai disampaikan melalui pengajaran yang berkualitas, peserta didik memahami konsekuensi (bagi diri mereka sendiri, orang lain, dan dunia secara luas) dari berbagai tindakan yang didasarkan dan yang tidak didasarkan nilai. 
c. Untuk menciptakan kemungkinan terwujudnya lingkungan belajar berbasis nilai, para pendidik tidak saja membutuhkan pendidikan bagi guru agar berkualitas, al

d. kan tetapi para pendidik ini juga perlu dihargai, diasuh, dan dipedulikan dalam lingkup komunitas belajar.

e. Dalam komunitas belajar berbasis nilai, hubungan positif berkembang dari kepedulian yang dimiliki setiap orang yang terlibat.

2. Prinsip terkait pendidikan nilai:

a. Pengembangan lingkungan berbasis nilai merupakan bagian yang integral dari pendidikan nilai, bukan sebuah pilihan.

b. Pendidikan nilai bukan hanya sebuah mata pelajaran dari sebuah kurikulum. Lebih dari itu, pendidikan nilai merupakan pedagogi, sebuah filosofi dan praktik pendidikan yang menginspirasi dan mengembangkan nilai-nilai positif di dalam kelas. Pengajaran berbasis nilai dan refleksi terbimbing mendukung proses pembelajaran sebagai proses pembuatan makna, berkontribusi pada pengembangan pemikiran kritis, imajinasi, pemahaman, kesadaran diri, keterampilan intrapersonal dan interpersonal serta pertimbangan orang lain.

c. Para pendidik nilai yang efektif menyadari akan pikiran, perasaan, sikap, dan perilaku mereka sendiri serta peka terhadap dampak yang ditimbulkannya terhadap orang lain.

d. Langkah pertama dalam pendidikan nilai adalah bagi para guru untuk mengembangkan persepsi yang jelas dan akurat mengenai literatur perilaku, sikap, dan emosional mereka sendiri sebagai alat bantu untuk menghidupkan nilai-nilai mereka sendiri. Selanjutnya, para guru akan dapat membantu mereka sendiri dan menguatkan orang lain untuk menggambarkan nilai-nilai personal, nilai-nilai kualitas kultural dan sosial, serta nilai-nilai warisan dan tradisi yang terbaik yang mereka sendiri miliki.

3. Prinsip terkait alam setiap individu dan lingkup pendidikan:

a. Pusat dari konsep pendidikan Living Values Education adalah sudut pandang setiap individu sebagai pola pikir, perasaan, penilaian manusia, yang secara kultural berbeda-beda dan akan tetapi saling memiliki sebagai satu keluarga dunia. Oleh karena itulah pendidikan harus fokus pada intelektualitas, emosional, spiritual dan kesejahteraan individu.

b. Wacana pendidikan, wacana pola pikir, wacana perasaan dan wacana penilaian, adalah bersifat analitis dan bebas tulis. Penetapan dialog mengenai nilai dalam konteks komunitas belajar berbasis nilai 
memfasilitasi perubahan interpersonal-dan bersifat cross-cultural terhadap pentingnya dan menjadi alat untuk menyampaikan nilai dalam pendidikan.

Program Living Values Education sendiri sudah disebarluaskan di ribuan lokasi dari berbagai negara dan para pengajar melaporkan bahwa para murid sangat menanggapi aktivitas-aktivitas nilai yang diberikan dan menjadi gemar berdiskusi dan mengaplikasikan nilai-nilai (Tillman, 2002:ix). Dalam laporan tersebut juga dinyatakan bahwa murid-murid menjadi lebih percaya diri, lebih menghargai orang lain dan menunjukkan peningkatan keterampilan sosial dan pribadi yang positif dan kooperatif.

Tujuan-tujuan LVEP (living values: an educational program) sendiri adalah:

a. membantu individu memikirkan dan merefleksikan nilai-nilai yang berbeda dan implikasi praktis bila mengekspresikan nilai-nilai tersebut dalam hubungannya dengan diri-sendiri, orang lain, masyarakat dan seluruh dunia;

b. memperdalam pemahaman, motivasi dan tanggung jawab saat menentukan pilihan-pilihan pribadi dan sosial yang positif;

c. menginspirasi individu memilih nilai-nilai pribadi, sosial, moral, dan spiritual dan menyadari metode-metode praktis dalam mengembangkan dan memperdalam nilai-nilai tersebut;

d. menolong para pengajar dan pengasuh memandang pendidikan sebagai sarana memberikan filsafat-filsafat hidup kepada para murid, dengan demikian memfasilitasi pertumbuhan, perkembangan, dan pilihan-pilihan mereka sehingga mereka bisa berintegrasi dengan masyarakat dengan rasa hormat, percaya diri, dan tujuannya jelas.

Bilamana selama ini beberapa sekolah dasar yang telah menerapkan pendidikan karakter, namun memperoleh hasil yang kurang maksimal, mungkin akan lebih baik bila mulai menerapkan program dari Living Values Education. Langkah-langkah serta aktivitas yang tersusun dalam program tersebut dapat sangat membantu para pengajar nilai. Selama ini memang beberapa sekolah telah menerapkannya, namun pengakuan dari para guru di beberapa Sekolah Dasar maupun Madrasah Ibtidaiyyah masih menemukan kesulitan. Contoh yang terjadi di dalam beberapa kelas di sebuah Madrasah Ibtidaiyyah di Kabupaten Banyuwangi adalah masih banyaknya murid yang berucap tidak sopan pada guru. Walaupun di beberapa sekolah tersebut juga disampaikan nilai-nilai agama pada para murid (Zidniyati:2017). 
Beberapa guru juga melaporkan bahwa kasus-kasus yang muncul di sekolah terkait sikap murid yang kurang sopan adalah konsistensi yang lemah dari para guru. Berdasarkan hasil observasi pada 5 sekolah dasar di Yogyakarta yang dilakukan pada November 2018 lalu, yang telah melakukan pendidikan nilai dengan cara membudayakan dalam seluruh kegiatan di sekolah, tidak hanya dalam muatan kurikulum, terlihat mengalami pencapaian yang lebih baik. Murid-murid dapat menuangkan ekspresi melalui berbagai kegiatan yang memang disusun secara lebih bervariasi oleh tim guru sekolah. Para guru juga lebih memiliki konsistensi yang tinggi pada komitmen untuk tujuan memahamkan nilai-nilai pada murid. Pengaturan waktu selama proses pembelajaran juga sangat bervariasi. Konten pelajaran juga lebih bervariasi dibandingkan dengan sekolah-sekolah yang mengalami pencapaian pendidikan nilai lebih rendah. Di beberapa sekolah di Banyuwangi, yang mengalami pencapaian hasil pendidikan nilai lebih rendah teramati bahwa memang tingkat konsistensi guru dalam menyampaikan pendidikan nilai dan selama proses pembelajaran tampak tidak konsisten (Zidniyati, 2018).

Ki Hadjar Dewantara menegaskan bahwa pendidikan bertujuan menuntun semua kekuatan kodrati yang dimiliki anak-anak, dengan tujuan agar anak-anak sebagai manusia dan juga selaku anggota masyarakat mampu meraih keselamatan dan kebahagiaan setinggi-tingginya. Oleh karenanya gagasan-gagasan yang didengungkan oleh Ki Hadjar Dewantara pun bertujuan untuk menjadikan anakanak sebagai manusia yang selamat dan bahagia. Ki Hadjar Dewantara mempopulerkan istilah tri pusat pendidikan. Menurut Ki Hadjar Dewantara (1961), istilah tri pusat pendidikan ini mengacu pada pengertian bahwa pendidikan itu berlangsung di tiga lingkungan, yakni di sekolah, keluarga, dan masyarakat.

Keluarga. Dalam sebuah hadist yang diriwayatkan oleh Bukhari dan Muslim dikisahkan bahwa Rosulullah Saw bersabda, "Setiap anak Adam (keturunan Adam) dilahirkan dalam keadaan fitrah, maka kedua orangtuanyalah yang menjadikannya Yahudi, Nasrani, atau Majusi." (HR. Bukhari dan Muslim). Dalam hadist tersebut diperlihatkan bahwa peran orangtua sangatlah besar bagi pendidikan seorang anak. Seorang anak akan dapat berperilaku sedemikian rupa sesuai dengan pendidikan yang diberikan oleh orangtuanya. Anak akan dapat berperilaku sebagaimana orang Yahudi, Nasrani, atau Majusi, atau lainnya, sesuai dengan bentuk-bentuk pendidikan yang diberikan orangtuanya. Bilamana bentuk dan lingkungan pendidikan yang diberikan orangtua pada anaknya adalah bentuk dan lingkungan yang baik, maka perilaku, sikap, akhlak, maupun karakter yang dimiliki anak tersebut akan mulia. Demikian juga sebaliknya, bilamana bentuk dan lingkungan pendidikan yang disajikan orangtua pada anaknya adalah bentuk dan 
lingkungan yang tidak baik, maka besar kemungkinan anak tersebut akan berperilaku tidak baik.

Guru. Setelah orangtua, ada peran pihak sekolah yang sangat penting, terutama peran seorang guru. Guru menjalankan peran orangtua bagi seorang murid selama berada di sekolah. Bilamana kewajiban orangtua kepada anak adalah membekali pendidikan keagamaan secara benar, maka demikian pula kewajiban guru di sekolah, yakni memberikan pembelajaran berbagai pengetahuan umum dan agama, hingga murid terbiasa menunaikan ibadah sesuai aturan agama. Maka karena hal inilah, setiap orangtua harus sangat jeli dalam memilih sekolah bagi anaknya. Akan sangat tepat bila orangtua menyekolahkan anaknya di sekolah yang mampu memberikan layanan pembelajaran secara komprehensif mengenai berbagai pengetahuan hingga keterampilan umum dan agama secara berimbang pada murid. Dan, akan sangat baik bila pihak guru juga mampu menjalin komunikasi yang interaktif dengan walimurid mengenai segala kemajuan murid.

Masyarakat. Pada akhirnya, ada satu lingkungan yang turut menentukan apakah orangtua dan guru berhasil menumbuhkembangkan nilai-nilai kebaikan pembangun karakter mulia pada anak, yakni lingkungan masyarakat dimana anak banyak menghabiskan sisa waktunya selain di keluarga dan sekolah untuk berinteraksi, yakni di lingkungan masyarakat. Dapat/tidaknya anak mempertahankan nilai-nilai kebaikan yang ditumbuhsuburkan dari keluarga maupun sekolah, akan teruji di lingkungan masyarakat. Demikianlah makna dari tri pusat pendidikan yang diajukan oleh Ki Hadjar Dewantara.

Wasitohadi (2014) memaknai gagasan John Dewey dengan menyatakan bahwa ukuran untuk segala perbuatan adalah manfaatnya dalam praktik dan hasil yang memajukan hidup. Benar tidaknya suatu hasil pikir, dalil maupun teori, dinilai menurut manfaatnya dalam kehidupan atau menurut berfaedah tidaknya teori itu dalam kehidupan manusia. Atas dasar inilah, tujuan sseseorang berfikir adalah untuk mendapatkan hasil akhir yang dapat membawa hidup seseorang lebih maju dan lebih berguna. Pendidikan bagi Dewey berbasis pada pengalaman, atau dalam terminologi Dewey sendiri "pengalaman" sebagai sarana dan tujuan pendidikan" (John Dewey, dalam Wasitohadi, 2004). Dewey yang terkenal dengan pemikiran pendidikan pragmatisme ini, menyumbangkan suatu gagasan bahwa segala pengalaman yang dimiliki oleh setiap peserta didik akan menyumbangkan suatu proses pembelajaran menjadi bermakna, atau berfaedah dalam kehidupan peserta didik tersebut. Pengalaman sebagai sarana bermakna melalui berbagai pengalaman yang diberikan atau yang dialami oleh seorang peserta didik, sebuah pemahaman akan suatu ilmu baru dapat diperoleh oleh peserta didik. Pengalaman sebagai tujuan dapat diuraikan bahwa tujuan dari sebuah pembelajaran adalah agar peserta didik mengalami sebuah proses yang diharapkan dalam suatu pendidikan. 
Kirschenbaum (1995: 31) menyatakan bahwa pendidikan nilai yang komprehensif menggunakan banyak metode dan kegiatan dari realisasi nilai-nilai, pendidikan karakter, pendidikan kewarganegaraan, dan gerakan pendidikan moral untuk membantu kaum muda menjalani kehidupan yang memuaskan secara pribadi dan kehidupan yang konstruktif secara sosial.Ada empat kategori pendidikan nilai-nilai komprehensif Kirschenbaum, yaitu: menanamkan nilai-nilai dan moralitas; memodelkan nilai-nilai dan moralitas; memfasilitasi nilai-nilai dan moralitas; dan keterampilan untuk pengembangan nilai dan melek moral. Penjelasan tentang empat elemen dari pendekatan komprehensif tersedia di bagian selanjutnya.

Menanamkan nilai-nilai dan moralitas dilakukan dengan unsur komunikasi. Pendidik akan menyampaikan satu nilai dengan diiringi satu penjelasan dan alasan yang dibutuhkan agar murid mampu memahami. Murid diajak untuk mengalami situasi sosial yang melibatkan nilai moral tertentu agar terlatih untuk mengambil sikap sesuai nilai yang disepakati dalam komunitas.

Memodelkan nilai-nilai moralitas ini mengandung makna bahwa setiap murid harus mendapatkan keteladanan dari semua orang dewasa di lingkungannya. Bilamana teladan yang ditampilkan oleh lingkungan adalah teladan yang baik, maka murid akan semakin mudah memahami dan membiasakan dirinya untuk bertindak sesuai nilai-nilai pembangun karakter yang dikembangkan.

Memfasilitasi nilai-nilai dan moralitas ini bermaksud memberikan kesempatan kepada siswa untuk melatih kemampuannya dalam pengambilan sikap sesuai nilai yang dikembangkan. Memberikan kesempatan dengan menempatkan murid pada berbagai aktivitas sosial, dapat membantu murid untuk belajar berfikir, merasakan, dan bertindak.

Pengembangan keterampilan akademik dan sosial adalah bertujuan untuk melatih murid berfikir kritis dan terampil mengatasi masalah. Ada keterampilan yang diperlukan untuk bergaul di dunia ini yang berhubungan langsung dengan mewujudkan nilai-nilai sendiri dan berperilaku secara konstruktif, sesuai moral dalam masyarakat. Para guru dan pendidik moral lainnya perlu memberikan pemahaman pada para murid untuk selalu melakukan pemikiran sebelum mengambil suatu tindakan. Berbagai kegiatan yang dapat melatih keterampilan siswa berfikir kritis dan terampil mengatasi masalah adalah yang perlu dikembangkan di sekolah. 


\section{SIMPULAN}

Berdasarkan berbagai kajian teori dan analisis praktik dalam pendidikan karakter yang diterapkna di ebebrapa sekolah, dapat diambil beberapa kesimpulan berikut ini.

1. Empat kemampuan yang harus dimiliki lulusan di era revolusi industri 4.0 adalah kemampuan memecahkan masalah, kemampuan berfikir kreatif, kemampuan berinovasi, dan kemampuan enterpreneurship.

2. Etika menjadi aspek penting dalam interaksi antar manusia di sepanjang era peradaban manusia.

3. Ada tri pusat pendidikan yang perlu bekerjasama untuk membelajarkan murid, yakni sekolah, keluarga, dan masyarakat.

4. Salah satu tugas pendidikan di era revolusi industri 4.0 adalah menguatkan pendidikan karakter dengan prinsip bahwa karakter dapat berubah sesuai dengan kesempatan dan lingkungan belajar yang diciptakan.

5. Proses pengembangan karakter diawali dengan pemberian pemahaman pada siswa tentang suatu nilai moral (moral knowing), dilanjutkan dengan pelibatan diri siswa secara emosional pada nilai yang diajarkan sehingga siswa meyakini bahwa nilai moral tersebut perlu dijadikan panduan dalam hidupnya (moral feeling), dan dimaknai dengan pembiasaan berperilaku sesuai nilai yang diyakini tersebut (moral action).

6. Pendidikan karakter dapat berhasil bilamana semua unsur pendidik melakukan aktivitas pengembangan nilai-nilai pembangun karakter secara konsisten dan bersama-sama.

7. Pendidikan karakter akan berhasil bilamana ada program yang tersusun secara terperinci yang disusun oleh pihak sekolah beserta pihak lain yang terkait. Salah satu program pendidikan karakter yang dapat diterapkan adalah program Living Values Education.

8. Pendekatan yang dapat diterapkan dalam pendidikan karakter dapat diprogramkan untuk 4 hal, yakni untuk menanamkan nilai-nilai, memberikan keteladanan, memfasilitasi, serta melakukan pengembangan keterampilan akademik dan sosial.

DAFTAR RUJUKAN :

Rohman, Abdul dan Ningsih, Yenni Eria. (2018). Pendidikan multikultural: penguatan identitas nasional di era revolusi industri 4.0. Proceeding Seminar Nasional Multidisiplin, Vol 1 No 1. ISSN: 2654-3184 (Online),(http://ejournal.unwaha.ac.id/index.php/snami/article/view/261 ), diakses 25 Januari 2019 
Drake, Christopher. (2016). Values education-principle and practice. Proceeding The $3^{\text {rd }}$ Summit Meeting on Education International Seminar Values-Based Learning for Wonderful Children. Yogyakarta, November 22 $2^{\text {nd }} 2016$. ISBN 978-602-74934-3-8. (Online), (http://digilib.uinsuka.ac.id/22774/1/Muammar\%20Qadafi\%20\%20CHARACTER\%20BUILDING\%20THROUGH\%20LIVING\%20VALUES\%2 0EDUCATION.pdf), diakses 25 Januari 2019

Heafford, M.R. (1967). Pestalozzi, his thought and its relevance today. London: Methuen \& Co Ltd

Dewantara, Ki Hadjar. (2013). Bagian pertama: pendidikan. Yogyakarta: Majelis Luhur Persatuan Taman Siswa

Kirschenbaum, Howard. (1995). 100 ways to enhance values and morality in schools and youth settings. Boston: Allyn and Bacon

Maemunah. (2018). Kebijakan pendidikan pada era revolusi industri 4.0. Prosiding seminar nasional Lembaga Penelitian dan Pendidikan Mandala. P-ISSN 26230291 E-ISSN 2623-2774. (Online), (http://ejournal.mandalanursa.org/index.php/Prosiding/article/view/423 ), diakses 26 Januari 2019

Moleong, Lexy J. (2006). Metodologi penelitian kualitatif. Bandung: Remaja Rosdakarya

Iswan dan Herwina. (2018). Membangun sinergitas dalam penguatan pendidikan karakter pada era ir 4.0. PROSIDING Seminar Nasional Pendidikan Era Revolusi. ISSN:2621-6477. (Online), (https://jurnal.umj.ac.id/index.php/SNP/issue/view/254/showToc), diakses 26 Januari 2019

Schwab, Klaus. (2016). The fourth industrial revolution. Geneva: World Economic Forum

Syamsuar dan Reflianto. (2018). Pendidikan dan tantangan pembelajaran berbasis teknologi informasi di era revolusi industri 4.0. Jurnal Ilmiah Teknologi Pendidikan, 2 (2). (Online, (http://ejournal.unp.ac.id/index.php/etech/article/view/101343), diakses 26 Januari 2019

Tillman, Diane G. (2016). The important of living value education for children. Proceeding The $3^{\text {rd }}$ Summit Meeting on Education International Seminar 
Values-Based Learning for Wonderful Children. Yogyakarta. ISBN 978-60274934-3-8. (Online), (http://digilib.uinsuka.ac.id/22774/1/Muammar\%20Qadafi\%20\%20CHARACTER\%20BUILDING\%20THROUGH\%20LIVING\%20VALUES\%2 0EDUCATION.pdf), diakses 26 Januari 2019

Tillman, Diane G. (2005). Living values: an educational progam; living values activities for children ages 8-14. Pendidikan nilai untuk anak usia 8-14 tahun. Alih bahasa oleh Adi Respati dkk. Jakarta: PT Grasindo.

Lickona, Thomas. (1992). Educating for character. Canada: Bantam books

Wasitohadi. (2014). Hakekat pendidikan dalam perspektif John Dewey: tinjauan teoretis. Jurnal Penelitian Pengembangan Kependidikan FKIP UKSW Salatiga. ISSN: 0854-5995.

(Online), (https://doi.org/10.24246/j.sw.2014.v30.i1.p49-61), diakses 26 Januari 2019

Zidniyati. (2017). The implementation of values comprehensive approach in developing character in an elementary school in Banyuwangi (an observational report). Proceeding International Conference on Islamic Education (ICIED), [S.l.], v. 2, n. 1, p. 286-298. (Online), (http://conferences.uin-malang.ac.id/index.php/icied/article/view/468), diakses 26 Januari 2019

Zidniyati. (2018). Building character by integrating local wisdom in islamic elementary school in Banyuwangi. JMIE : Journal of Madrsah Ibtidaiyah Education, p-ISSN: 2580-0868, e-ISSN: 2580-2739, (Online), (http://ejournal.adpgmiindonesia.com/index.php/jmie/article/view/61), diakses 26 Januari 2019 